\title{
OBSERVATIONS ON THE THERMAL SELECTION OF THE PANTANAL CAIMAN (Caiman crocodilus yacare) HATCHLINGS (Crocodylia: Alligatoridae)
}

\author{
PINHEIRO, M. S., ${ }^{1}$ ANDREOTTI E SILVA, R. ${ }^{2}$ and SANTOS, S. A. ${ }^{3}$ \\ ${ }^{1}$ Embrapa, Clima Temperado, CPACT, C.P. 553, CEP 96001-970, Pelotas, RS, Brazil \\ ${ }^{2}$ Embrapa, Gado de Corte, CNPGC, C.P. 154, CEP 79080-900, Campo Grande, MS, Brazil \\ ${ }^{3}$ Embrapa, Pantanal, CPAP, C.P. 109, CEP 79300-950, Corumbá, MS, Brazil \\ Correspondence to: Max Silva Pinheiro, Embrapa, Clima Temperado, Estação Experimental Terras Baixas, Capão \\ do Leão s/nº, Campus UFPEL, C.P. 553, CEP 96001-970, Pelotas, RS, Brazil, \\ e-mail: maxsp@cpact.embrapa.br \\ Received March 9, 2000 - Accepted April 25, 2000 - Distributed May 31, 2001
}

\begin{abstract}
Three options of water temperatures in a thermal gradient that changed from 22 to $35^{\circ} \mathrm{C}$ were offered to Pantanal caiman (Caiman croocodilus yacare) hatchlings. Animals from two nests were submitted to temperatures during 19 days (Nest 1 - 20 caimans caught in the nature hours after hatching), corresponding to 1 to 7 observations periods, and 13 days (Nest $2-20$ animals obtained by artificial incubation) relative to observation period 8. Caimans remain fasting during experimental period. Hatchlings were allocated in a enclosure containing three styrofoam boxes $(120 \mathrm{~L})$ disposed side by side enclosed by wire netting and filled with water to the top. Thus, the animals were free to access the boxes, which temperatures were changed at the end of each observation period to avoid position effects. Air temperature was keep close to $22^{\circ} \mathrm{C}$ by air conditioning and water temperature was controlled by thermostats. The trial was divided in three phases determined by elimination of the less frequented temperature and its substitution by another temperature. In a first phase of the experiment that contained 1, 2 and 3 observation periods, the thermostats were regulated to $22^{\circ} \mathrm{C}$ (BoxD), $26^{\circ} \mathrm{C}$ $(\mathrm{BxC})$ and $32^{\circ} \mathrm{C}(\mathrm{BxA})$. In phase 2 to $26^{\circ} \mathrm{C}, 29.5^{\circ} \mathrm{C}(\mathrm{BxB})$ and $32^{\circ} \mathrm{C}$, including 4,5 and 6 periods. In the third phase that included 7 and 8 periods, the thermostats were adjusted to $29.5^{\circ} \mathrm{C}, 32^{\circ} \mathrm{C}$ and $35^{\circ} \mathrm{C}(\mathrm{BxE})$. The number of caimans in each box was recorded two to three times a day (8:00, 14:00 and 17:00h) before pointed water temperature. Mean water temperatures $( \pm$ standard deviation $)$ and respective caiman frequency means by box/temperature were: Phase $1\left(\mathrm{BxD} / 22.3 \pm 1.2^{\circ} \mathrm{C}-10.3 \%\right.$; $\mathrm{BxC} / 27.0 \pm 2.4^{\circ} \mathrm{C}-32.0 \%$ and $\left.\mathrm{BxA} / 31.2 \pm 1.1^{\circ} \mathrm{C}-57.6 \%\right)$; Phase $2\left(\mathrm{BxC} / 26.6 \pm 2.8^{\circ} \mathrm{C}-13.3 \%\right.$; $\mathrm{BxB} / 29.3 \pm 2.2^{\circ} \mathrm{C}-27.7 \%$ and $\left.\mathrm{BxA} / 31.3 \pm 1.2^{\circ} \mathrm{C}-59.0 \%\right)$ and Phase $3\left(\mathrm{~B} \times \mathrm{B} / 29.5 \pm 3.6^{\circ} \mathrm{C}-23.7 \%\right.$; $\mathrm{BxA} / 31.0 \pm 2.2^{\circ} \mathrm{C}-31.9$ and $\left.\mathrm{BxE} / 34.0 \pm 2.2^{\circ} \mathrm{C}-44.4 \%\right)$. Observing that in the phases 1 and 2 the box with hottest water (CxA) was more frequented. In the phase 3 , the difference between higher and smaller frequency straiten to $20.7 \%$, in relation to almost $46.5 \%$ in phases 1 and 2 , indicating that water temperatures between 29.5 and $35^{\circ} \mathrm{C}$ resulted in body temperatures more next to the comfort zone, in the experimental conditions.
\end{abstract}

Key words: caiman, hatchlings, Pantanal, thermal selection, water temperature.

\section{RESUMO}

Observações sobre a preferência térmica de filhotes recém-eclodidos do jacaré-doPantanal (Caiman crocodilus yacare; Crocodylia: Alligatoridae)

Três opções de temperatura da água, em um gradiente térmico que variou de 22 a $35^{\circ} \mathrm{C}$, foram oferecidas a filhotes recém-eclodidos do jacaré-do-Pantanal (Caiman crocodilus yacare). Os animais, 
provenientes de dois ninhos, foram submetidos às temperaturas durante 19 dias (Ninhada 1 - 20 jacarés capturados no campo, horas após a eclosão), correspondendo aos períodos de observação 1 a 7 , e 13 dias (Ninhada 2 - 21 animais obtidos por incubação artificial) referentes ao oitavo período de observação. Os jacarés permaneceram em jejum durante o período experimental. Os filhotes foram alocados em um recinto contendo três caixas de isopor $(120 \mathrm{~L})$ dispostas lado a lado, cercadas com tela de viveiro e completadas com água até o topo. Desse modo, os animais tinham trânsito livre entre as caixas, cujas temperaturas foram trocadas ao término de cada período de observação para evitar efeito de posição. A temperatura do ar foi mantida em torno de $22^{\circ} \mathrm{C}$ por meio de um condicionador de ar e a da água foi controlada por termostatos. O ensaio foi dividido em três fases determinadas pela eliminação da temperatura menos freqüentada e sua substituição por uma outra temperatura. Em uma primeira fase do experimento, que compreendeu os períodos de observação 1, 2 e 3, os termostatos foram regulados para $22^{\circ} \mathrm{C}(\mathrm{CaixaD}), 26^{\circ} \mathrm{C}(\mathrm{CxC})$ e $32^{\circ} \mathrm{C}(\mathrm{CxA})$. Na Fase 2 , para $26^{\circ} \mathrm{C}, 29,5^{\circ} \mathrm{C}$ e $32^{\circ} \mathrm{C}(\mathrm{CxB})$, englobando os períodos 4,5 e 6 . Na terceira fase, que incluiu os períodos de observação 7 e 8 , os termostatos foram ajustados para $29,5^{\circ} \mathrm{C}, 32^{\circ} \mathrm{C}$ e $35^{\circ} \mathrm{C}(\mathrm{CxE})$. O número de jacarés em cada caixa foi registrado duas a três vezes ao dia $(8 \mathrm{~h}, 14 \mathrm{~h} \mathrm{e} 17 \mathrm{~h})$ antes de anotar a temperatura da água. As temperaturas médias da água ( \pm desvio-padrão) e as respectivas médias de freqüência de jacarés por caixa/temperatura foram: Fase $1\left(\mathrm{CxD} / 22,3 \pm 1,2^{\circ} \mathrm{C}-10,3 \% ; \mathrm{CxC} / 27,0 \pm 2,4^{\circ} \mathrm{C}-32,0 \%\right.$; e CxA/31,2 $\left.\pm 1,1^{\circ} \mathrm{C}-57,6 \%\right)$; Fase $2\left(\mathrm{CxC} / 26,6 \pm 2,8^{\circ} \mathrm{C}-13,3 \%\right.$; $\mathrm{CxB} / 29,3 \pm 2,2^{\circ} \mathrm{C}-27,7 \%$; e $\mathrm{CxA} /$ $\left.31,3 \pm 1,2^{\circ} \mathrm{C}-59,0 \%\right)$; e Fase $3\left(\mathrm{CxB} / 29,5 \pm 3,6^{\circ} \mathrm{C}-23,7 \% ; \mathrm{CxA} / 31,0 \pm 2,2^{\circ} \mathrm{C}-31,9 \%\right.$; e $\mathrm{CxE} /$ $\left.34,0 \pm 2,2^{\circ} \mathrm{C}-44,4 \%\right)$. Observa-se que, nas Fases 1 e 2 , a caixa com água mais quente (CxA) foi a mais freqüentada. Na Fase 3, a diferença entre a maior e a menor frequiência se estreitou para 20,7\%, em relação aos cerca de 46,5\% nas Fases 1 e 2, indicando que as temperaturas de água entre 29,5 e $35^{\circ} \mathrm{C}$ resultaram em temperaturas corporais mais próximas da zona de conforto, nas condições do experimento.

Palavras-chave: filhotes recém-eclodidos, jacaré, Pantanal, preferência térmica, temperatura da água.

\section{INTRODUCTION}

The crocodilians depend on the external temperature to live, they are ectotermics but they don't live to regulate their temperature. Occasionally, these animals are exposed to high and low temperatures due to the presence of predators, illness, migratory movements etc. Normally the crocodilians spend most of their time in the water, being this the most important factor which determine its body temperature. Nevertheless, when the animals are exposed to the sun or are on the water surface, where is hotter, they can obtain higher temperatures, necessary to its better digestion and growth. This way, the hatchlings can obtain heating faster than the adults because of its less mass/surface relation.

We know that the incubation temperature, the feed/fast, the infections, the sex and the social interactions, may affect the alligator hatchling selected temperature and probably of the other crocodilians too. The animals (Crocodylus sia- mensis) obtained in higher incubation temperatures $\left(32.5-33^{\circ} \mathrm{C}\right.$; males) select higher temperatures in relation to the ones coming from lower incubation temperatures $\left(27.5-28^{\circ} \mathrm{C}\right.$; females). The appetite is dependent of the temperature and consequently the growth. After a meal the alligators select higher temperatures and during the fast they choose lower temperatures to decrease the metabolism and save energy. Animals with infections present thermophily to increase the immune-defense efficiency. The alligator hatchlings present a slight thermophily $\left(32.5^{\circ} \mathrm{C}\right.$, decreasing to $27-28^{\circ} \mathrm{C}$ in a month - in fast) when submitted to a thermal gradient, which is associated to the best absorption of the yolk, being that demonstrated to other crocodilian species (Lang, 1987).

The alligator metabolic rate (oxygen consumption) is increased in $30 \%$ when body temperature is elevated from 28 to $29^{\circ} \mathrm{C}$ (Coulson \& Coulson, 1986), showing that differences of about $1^{\circ} \mathrm{C}$ may have a great importance in the valuation of suitable temperatures. Pinheiro et al. (1992) 
observed that the growth of Pantanal caiman hatchlings (Caiman crocodilus yacare) is greater between 29.5 and $32^{\circ} \mathrm{C}$ than at $26^{\circ} \mathrm{C}$. At $22^{\circ} \mathrm{C}$ the food consumption and the growth were almost invalid, agreeing with the data of Coulson \& Hernandez (1983). Brandt (1990) observations, carrying caimans (Caiman crocodilus) of about 37 to $80 \mathrm{~cm}$, from Florida to South Caroline, showed that they can die if exposed to $10^{\circ} \mathrm{C}$ for six hours. Diefenbach (1988) observed that Caiman latirostris, a specie that lives on higher latitude, lives in water bodies which the lower temperatures can go to $9^{\circ} \mathrm{C}$ for several days during the winter. It was suggested that adult caimans of this specie don't eat for 5 to 6 months during the cold period.

According to Diefenbach (1975) the selected temperatures for Caiman crocodilus of 0.15 to $6 \mathrm{~kg}$ varying from 29.9 to $34.8^{\circ} \mathrm{C}$ in a ground-water gradient generated by infra-red lamps, but there wasn't any offers of intermediate and high water temperatures, and prevailed the exposed of animals on the dry area, as the lamps were located on this area. Alligators of 37.5 to $90 \mathrm{~cm}$ (TL) selected average body temperatures of $32^{\circ} \mathrm{C}$, varying between 29.9 and $35.6^{\circ} \mathrm{C}$, according Johnson et al. (1978). Caiman latirostris of 0.5 to 5.5 years old selected temperatures of 18.5 to $36^{\circ} \mathrm{C}$ in enclosures located inside a plastic greenhouse (Verdade et al., 1994). Molina \& Sajdak (1993) studied the thermal selection of Caiman latirostris of 1.1 to $26 \mathrm{~kg}$ with telethermometers, in enclosures of the São Paulo Zoo, and suggested that the young select temperatures among 29 and $34.5^{\circ} \mathrm{C}$.

Smith (1972) quoted by McNease \& Joanen (1974), noted that the alligator (Texas) preferred temperature was between 32 and $35^{\circ} \mathrm{C}$, but indicated that the optimum temperature to the young was 28.8 to $30^{\circ} \mathrm{C}$ (Louisiana). Colbert et al. (1946) indicated that the superior limit of the body temperatures, lethal to the alligator, is $38.5^{\circ} \mathrm{C}$ and that the ideal temperature during the basking is 32 to $35^{\circ} \mathrm{C}$. To Lang (1987), experiments of Colbert et al. (1946), Johnson et al. (1978), and Diefenbach (1975) impute body temperatures selected on the superior limit of the body temperatures spontaneously selected and do not include lower values, because the animals were confined specially on ground or submitted to heating experiments.

Wilbur (1960) observed that temperatures of $34^{\circ} \mathrm{C}$ have a dangerous effect, due to a remar- kable fluctuation on the cardiac rate and, at $40^{\circ} \mathrm{C}$ the damage to the heart of the alligator is irreversible. Coulson \& Hernandez (1983) suggested that the optimum temperature to the growth of Alligator mississippiensis is maybe around 32 to $33^{\circ} \mathrm{C}$, pointing out that these animals do not feed themselves during the cold period of approximately six months. The Crocodylus porosus preferred temperature was among 32 and $33^{\circ} \mathrm{C}$ (Johnson et al., 1976). This study was part of a pilot research to determine the captivity handling to the Pantanal caiman and was carried out to evaluate the thermal selection of the hatchlings in thermal gradient with different sequences of water temperatures.

\section{MATERIAL AND METHODS}

This study was carried out at Centro de Pesquisa Agropecuária do Pantanal (CPAP/Embrapa) in Corumbá, State of Mato Grosso do Sul, Brazil. Three options of water temperature, in a thermal gradient which varied from 22 to $35^{\circ} \mathrm{C}$, were provided to Pantanal caiman (Caiman crocodilus yacare) hatchlings. The animals, from two different nests were submitted to the gradient during 19 days (Nest $1-20$ caimans caught in the nature hours after eclosion), corresponding to the $1,2,3,4,5$, 6 , and 7 observation periods, and 13 days (Nest $2-21$ animals obtained by artificial incubation at the environment temperature) referring to the $8^{\text {th }}$ observation period. The hatchlings were not fed during the study, counting on their yolk stock to survive.

The caimans were located in a enclosure containing three styrofoam box (120 L) $\left(0.48 \mathrm{~m}^{2}\right)$ disposed side by side and enclosed by wire netting (50 $\mathrm{cm}$ high to stop from escape), being filled with water to the top. This way, the caimans were free to access the boxes, which the water temperatures were randomizedly changed at the end of each observation period to avoid positions effects. The air temperature inside the small room was kept around $22^{\circ} \mathrm{C}$ by air conditioning and the water temperature was controlled by thermostats with heaters of $100 \mathrm{~W}$. At $50 \mathrm{~cm}$ from the water were located fluorescent lamps which were on for 9 hours during the day.

At the beginning of the study the caimans were distributed in equable lots in each box. The only dry area was the border of the styrofoam box 
(around $5 \mathrm{~cm}$ ) and there was a repose wood platform $(15 \times 40 \mathrm{~cm})$ located around $2 \mathrm{~cm}$ below the water. Doing only one water change as it wasn't provided any food.

The experiment was divided into three phases determined by elimination of the less frequented temperature and its substitution by a higher temperature. The number of caimans in each box was recorded twice or three times a day $(8 \mathrm{am}, 2 \mathrm{pm}$, and $5 \mathrm{pm}$ ) before pointing the water temperature. Counting fast, first the caimans in the boxes where there were a lower number of caimans and so obtaining the result of the last box, the most frequented, by difference.

In the first phase of the experiment, that contained $1(n=10$ readings $), 2(n=5)$ and $3(n=$ 2) observation periods, the thermostats were regulated to $22^{\circ} \mathrm{C}(\mathrm{BxD}), 26^{\circ} \mathrm{C}(\mathrm{BxC})$ and $32^{\circ} \mathrm{C}(\mathrm{BxA})$. In the second phase they were fit to $26^{\circ} \mathrm{C}, 29.5^{\circ} \mathrm{C}$ $(\mathrm{BxB})$ and $32^{\circ} \mathrm{C}$, including $4(\mathrm{n}=21), 5(\mathrm{n}=6)$ and $6(n=10)$ observation periods. In the third phase, that included the observations periods 7 ( $\mathrm{n}=$ $3)$ and $8(n=34)$, the thermostats were set to $29.5^{\circ} \mathrm{C}, 32^{\circ} \mathrm{C}$ and $35^{\circ} \mathrm{C}(\mathrm{BxE})$.

\section{RESULTS AND DISCUSSION}

The average of the water temperatures $( \pm$ standard deviation) and the respective average of the caiman frequency percentage by box/temperature were:

$$
\begin{array}{r}
\text { Phase } 1\left(\mathrm{BxD} / 22.3 \pm 1.2^{\circ} \mathrm{C}-10.3 \%\right) \\
\left(\mathrm{BxC} / 27.0 \pm 2.4^{\circ} \mathrm{C}-32.0 \%\right) \\
\left(\mathrm{BxA} / 31.2 \pm 1.1^{\circ} \mathrm{C}-57.6 \%\right) \\
\text { Phase } 2\left(\mathrm{BxC} / 26.6 \pm 2.8^{\circ} \mathrm{C}-13.3 \%\right) \\
\left(\mathrm{BxB} / 29.3 \pm 2.2^{\circ} \mathrm{C}-27.7 \%\right) \\
\left(\mathrm{BxA} / 31.3 \pm 1.2^{\circ} \mathrm{C}-59.0 \%\right) \\
\text { Phase } 3\left(\mathrm{BxB} / 29.5 \pm 3.6^{\circ} \mathrm{C}-23.7 \%\right) \\
\left(\mathrm{BxA} / 31.0 \pm 2.2^{\circ} \mathrm{C}-31.9 \%\right) \\
\left(\mathrm{BxE} / 34.0 \pm 2.2^{\circ} \mathrm{C}-44.4 \%\right)
\end{array}
$$

The Chi-square test applied in Phases $1\left(\mathrm{c}^{2}=\right.$ 92.5), $2\left(c^{2}=100.8\right)$ and $3\left(c^{2}=76.0\right)$ indicated that there were significative differences $(\mathrm{p}<0.05)$ in the caimans frequency among the different temperatures. Noting that in Phases 1 and 2 the difference between the higher and lower frequency was around $46.5 \%$ and in Phase 3, where the temperatures offered were higher, this difference was close to $20.7 \%$, indicating that the temperatures between 29.5 and $35^{\circ} \mathrm{C}$ were the temperature closest to the comfort zone, in the experiment conditions. The highest frequencies of caimans in the eight periods were verified in medium water temperatures between $27.45^{\circ} \mathrm{C}$ and $33.89^{\circ} \mathrm{C}$, with a general average of $31.39 \pm 1.97^{\circ} \mathrm{C}(\mathrm{n}=8)$.

The Caiman crocodilus yacare hatchlings selected temperatures as high as $34^{\circ} \mathrm{C}$. Nevertheless, the existence of air temperature of $22^{\circ} \mathrm{C}$, in this study, allowed that the animals can expose parts of the body (specially the head) out of the water, indicating that the body temperature should be a little bit lower than the temperature verified in the water. This suggest that we could use water temperatures as high as $38-40^{\circ} \mathrm{C}$, so to obtain all the answer curve. Besides, the use of temperature electronic sensors located in the animals stomach (Lang, 1987) would allow a better approximation to the body temperatures selected in the several hours during the day and a higher number of observations in a small time.

The caimans did not present thermal chock problems caused by the contrast between the airwater temperature, verified by Pinheiro et al. (1992), probably because there was an opportunity to choose the different body temperatures by the animals and the water wasn't frequently changed exposing the animals to the contrast. The crocodilian hatchlings tend to present thermophily in the yolk absorption period which can last for more than two months (personal observation), according to the body temperature. On the other hand, alligators in fast tend to choose lower temperatures (Lang, 1987). Due to the chosen high temperatures, it is probable that the caimans of this experiment presented thermophily even when in fast. However, it was postulated that more tropical species, as the crocodilians from Brazil, tend to adopt a strategy of thermoconformity and not to search for higher body temperatures as it is the case of the American Alligator, which is the crocodilian able to live in the highest latitude and in lower temperatures (Lang, 1987).

Joanen \& McNease (1977) kept higher temperatures $\left(32.2\right.$ to $\left.33.3^{\circ} \mathrm{C}\right)$ in the environmental chambers during the first ten days of the alligator life to increase the yolk absorption rate and antecipate the beginning of the food supplying. Pinheiro et al. (1997), incubated eggs of Caiman crocodilus yacare in temperatures of 28 to $34^{\circ} \mathrm{C}$, and the animals obtained in this last temperature 
(93\% male) showed an excellent health condition. Vianna (1995) tested the temperatures of 30, 32, and $34^{\circ} \mathrm{C}$ for Caiman latirostris hatchlings in growth experiment and the animals in the higher temperature do not present any problems unless higher consumption and worse food conversion, and not obtaining, this way, better growth. These studies and the data of this experiment indicate that caimans hatchlings can be submitted to temperatures of $34 \pm 2^{\circ} \mathrm{C}$ to faster yolk absorption during the first weeks of life.

\section{REFERENCES}

BRANDT, L. A., 1990, The behavior of juvenile Alligator mississippiensis and Caiman crocodilus exposed to low temperature. Copeia, 3: 867-871.

COLBERT, E. H., COWLES, R. B. \& BOGERT, C. M., 1946, Temperature tolerances in the American Alligator, and their bearing on the habits, evolution and extinction of the dinosaurs. Bull. Amer. Mus. Nat. Hist., 86: 333-373.

COULSON, R. A. \& COULSON, T. D., 1986, Effect of temperature on the rates of digestion, aminoacid absorption and assimilation in the alligator. Comp. Biochem. Physiol., 83A(3): 585-588.

COUlSON, R. A. \& HERNANDEZ, T., 1983, Alligator metabolism: Studies on Chemical Reactions in Vivo. Pergamon Press, Oxford, 182p.

DIEFENBACH, C. O., 1975, Thermal preferences and thermoregulation in Caiman crocodilus. Copeia, 1975: 530540 .

DIEFENBACH, C. O., 1988, Thermal and feeding relations of Caiman latirostris (Crocodylia: Reptilia). Comp. Biochem. Physiol., 89A: 149-155.

JOANEN, T. \& McNEASE, L., 1977, Artificial incubation of alligator eggs and post hatching culture in controlled environmental chambers. Proceedings of the Annual Meeting World Mariculture. Society, San Jose, 1977. Louisiana State University School of Forestry and Wildlife Management, 8: 483-490.

JOHNSON, C. R., VOIGT, W. G. \& SMITH, E. N., 1978, Thermoregulation in crocodilians. III. Thermal preferenda, voluntary maxima, and heating and cooling rates in the American Alligator, Alligator mississippiensis. Zool. J. Linnean Soc., 62: 179-188.
JOHNSON, C. R., WEBB, G. J. W. \& TANNER, C., 1976, Thermoregulation in crocodilians. II. A telemetric study of body temperature in the Australian crocodiles, Crocodylus johnstoni and Crocodylus porosus. Comp. Biochem. Physiol., Ser. A, 53: 143-146.

LANG, J. W., 1987, Crocodilian thermal selection. In: G. J. W. Webb, S. C. Manolis \& P. J. Whitehead (eds.), Wildlife management: crocodiles and alligators. Chipping Norton, Surrey Beatty and Sons Pty. Chapter 29, pp. 295-300.

McNEASE, L. \& JOANEN, T., 1974, A study of immature alligators on Rockefeller Refuge, Louisiana. In: Proceedings of the Annual Conference of the South-eastern Association of Game and Fish Commissioners, 1974. Department Wildlife and Fisheries, Baton Rouge, 28: 482-500.

MOLINA, F. B. \& SAJDAK, R. A., 1993, Observações sobre a preferência térmica e o comportamento de termorregulação no jacaré-do-papo-amarelo, Caiman latirostris, em cativeiro: variações ontogenéticas e algumas comparações com outras espécies de jacarés neotropicais. In: L. M. Verdade, I. U. Packer, M. B. Rocha, F. B. Molina, P. G. Duarte \& L. A. B. Lula (eds.), Workshop sobre conservação e manejo do jacaré-do-papo-amarelo (Caiman latirostris), 3, Piracicaba, 1992. Anais. USP/Esalq, Piracicaba, pp. 93-132.

PINHEIRO, M. S., MOURÃO, G. de M., CAMPOS, Z. M. da \& COUTINHO, M. E., 1997, Influência da temperatura de incubação na determinação do sexo do jacaré (Caiman crocodilus yacare). Rev. Brasil. Biol., 57(3): 383-391.

PINHEIRO, M. S., SANTOS, S. A. \& SILVA, R. A. e, 1992, Efeito da temperatura da água sobre o crescimento inicial de Caiman crocodilus yacare. Rev. Brasil. Biol., 52(1): 161-168.

VERDADE, L. M., PACKER, I. U., MICHELLOTI, F. \& RANGEL, M. C., 1994, Thermoregulatory behavior of broad snouted caiman (Caiman latirostris) under different thermal regimes. In: Workshop sobre conservación y manejo del yacare overo Caiman latirostris, 4, Santa Fe, 1993. Memorias. Santa Fe: "La Región" - Fundación Banco Bica, pp. 84-94.

VIANNA, V. O., 1995, O efeito da temperatura no desenvolvimento de filhotes de jacaré-do-papo-amarelo, Caiman latirostris (Daudin, 1802) em cativeiro. Dissertação de Mestrado, Escola Superior de Agricultura Luiz de Queiroz/USP, Piracicaba, 73p.

WILBUR, C. G., 1960, Effect of temperature on the heart of the Alligator. Am. J. Physiology, 198: 861-863. 